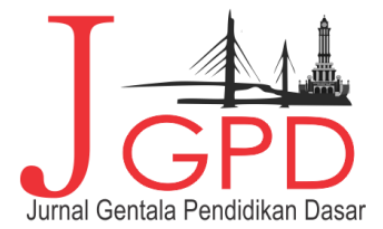

Research Article

\title{
Pelaksanaan Penilaian Portofolio Di Sekolah Dasar
}

\author{
Eko Kuntarto, Rahani Gustina
}

Program Studi Pendidikan Guru Sekolah Dasar, FKIP, Universitas Jambi, Jambi, Indonesia

\section{Article Information}

Reviewed : Nov 7, 2019

Revised : Nov 20, 2019

Available Online : Des 27, 2019

\section{Keyword}

Implementation, portfolio

assessment

\section{Corespondence}

e-mail :

abieko28@gmail.com

\section{ABSTRACT}

This portfolio assessment has been widely applied in primary schools in Indonesia. In practice portfolio assessment has been widely used for the teacher certification process. This study aims to describe the implementation of portfolio assessment and describe the results of the implementation of portfolio assessment in elementary schools. The approach in this study uses a qualitative approach. While the type of research used in this study is the basic theory. This research was carried out at Muara Bulian 80 / I Elementary School, Batang Hari Regency, Jambi Province. Data collection techniques used are non-participant observation, interviews, and documentation. Researchers use the Miles and Hubermen model to analyze existing data. The model is to carry out the stages that begin with collecting data, reducing, displaying data, and verifying or drawing final conclusions. This research was conducted in the even semester of the Academic Year 2017/2018. From the results of the study concluded that portfolio assessment which includes content, assessment criteria and forms of presentation of student portfolios developed by teachers include, daily tests, book reading reports, self-assessment sheets, inter-theme assessment sheets, and for class 1 also included books homework, practice books, dictation assignments and coloring

\section{DOI : https://doi.org/10.22437/gentala.v4i2.8437}

\section{PENDAHULUAN}

Penilaian yang diartikan sebagai proses untuk mengumpulkan dan mengolah informasi dari pencapaian hasil belajar peserta didik. Penilaian yang dijadikan sebagai pedoman untuk menilai pada pendidikan sekolah dasar yang mencakupi: penilaian otentik, penilaian diri, penilaian berbasis portofolio, ulangan, ulangan harian, ulangan tengah semester, ulangan akhir semester, ujian tingkat kompetensi, ujian mutu tingkat kompetensi, ujian nasional, dan ujian sekolah. Sesuai peraturan menteri pendidikan dan kebudayan republik Indonesia nomor 23 tahun 2016 tentang standar penilaian pendidikan adalah kriteria mengenai ruang lingkup dari manfaat, tujuan, mekanisme, prosedur, prinsip, dan instrumen dari hasil penilaian belajar peserta didik.

Dalam standar kompetensi lulusan yang memiliki tujuan untuk menyeimbangkan dan meningkatkan antara aspek pengetahuan, sikap, dan keterampilan. Berdasarkan permasalah 


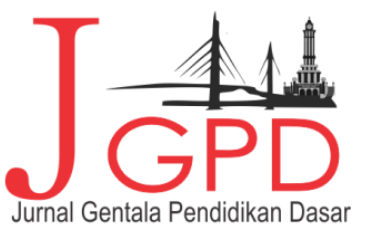

JURNAL GeNTALA PENDIDIKAN DASAR Vol. 4 No. 2 December 2019, Page I90-200 P-ISSN : 2614-7092, E-ISSN : 2621-961I

Available Dnline at Web : http://online-journal.unja.ac.id/index.php/gentala email : penyunting.jurnal.g-pgsd国unja.ac.id

yang terungkap, oleh karenanya, perlu diupayakan pelaksanaan suatu perspektif penilaian. Yaitu, penilaian portofolio yang dilaksanakan pada kurikulum 2013. Penilaian portofolio sebenarnya bukanlah bentuk penilaian yang baru, dalam KBK (kurikulum berbasis kompetensi) atau kurikulum 2004, penilaian portofolio menjadi salah satu kewajiban untuk dilakukan guru kelas.

Dalam praktiknya penilaian portofolio telah banyak digunakan untuk proses sertifikasi guru.Penilaian portofolio ini juga sudah banyak diterapkan di sekolah-sekolah dasar di Indonesia. Dari hasil observasi sementara yang dilakukan di SDN-SDN yang ada di Kabupaten Batanghari, diantaranya di SDN 186/1 Sridadi, SDN 198/1 Pasar Baru, SDN 182/1 Hutan Lindung, dan di SDN 80/1 Muara Bulian. Di SDN 80/1 Muara Bulian telah menerapkan penilaian portofolio, portofolio siswa di SDN 80/1 Muara Bulian dipajang di dinding kelas dengan map-map tergantung. Portofolio ini dijadikan dasar untuk melihat dan menilai proses perkembangan pengetahuan, keterampilan, dan sikap dari peserta didik, menjadi bukti tentang apa yang dapat dilakukan oleh peserta didik selama pembelajaran. Portofolio ini dapat diartikan sebagai kumpulan hasil karya peserta didik yang didokumentasikan secara teratur. Portofolio ini berupa tugas-tugas yang dikerjakan oleh peserta didik, catatan dari hasil observasi guru, beberapa prestasi, karangan yang dikerjakan peserta didik dan laporan kegiatan peserta didik, dan catatan-catatan negatif yang dilakukan peserta didik.

Berdasarkan kriteria dari penilaian portofolio tidak hanya menekankan pada ranah kognitif saja, tetapi juga nilai, sikap, serta keterampilan. Dengan penggunaan penilaian portofolio, peserta didik juga dapat melihat hasil belajarnya dari waktu ke waktu, memberikan peserta didik kesempatan untuk ikut serta dalam menilai hasil belajar dirinya sendiri. Penilaian portofolio dapat digunakan untuk meningkatkan kemampuan peserta didik melalui penilaian umpan balik dan penilaian sendiri. Isi dari portofolio akan menjadi perhatian utama bagi guru dalam program mengajarnya. Oleh karena itu, judul penelitian ini yaitu "Pelaksanaan Penilaian Portofolio Guru Terhadap Siswa Di Sekolah Dasar".

\section{METODE PENELITIAN}

Penelitian ini dilakukan di Sekolah Dasar Negeri 80/I Muara Bulian, Kabupaten Batang Hari, Provinsi Jambi. Yang dilaksanakan pada semester genap Tahun Pelajaran 2017/2018. 


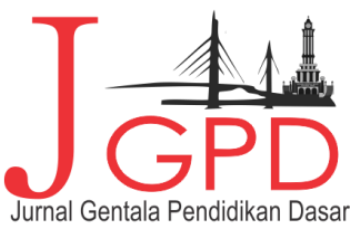

Available Online at Web : http://online-journal.unja.ac.id/index.php/gentala email : penyunting.jurnal.q-pgsd国unja.ac.id

Pendekatan dalam penelitian ini menggunakan pendekatan kualitatif. Pendekatan kualitatif digunakan untuk menguraikan, menggambarkan, menggali dan mendeskripsikan yang berkaitan dengan penelitian ini. Sedangkan Jenis penelitian yang digunakan dalam penelitian ini yaitu, teori dasar. Penelitian menggunakan jenis teori dasar adalah penelitian yang diarahkan pada penemuan atau menguatkan teori. Penelitian ini dilakukan dengan melakukan studi perbandingan antar kategori, fenomena dan situasi dari data yang diperoleh. Berdasarkan tujuan dari penelitian ini adalah untuk mendeskripsikan penilaian portofolio yang dilakukan oleh guru terhadap siswa dan mendeskripsikan hasil dari penggunaan penilaian portofolio tersebut.

Penelitian ini untuk mendapatkan data deskripsi mengenai pelaksanaan penilaian portofolio yang dilakukan guru terhadap siswa, dan deskripsi hasil yang di peroleh guru dan siswa dalam melaksanakan proses penilaian portofolio tersebut.Sumber data dari penelitian ini yaitu; kegiatan pelaksanaan penilaian portofolio yang dilaksanakan oleh guru kelas dan siswa di kelas I- VI di Sekolah Dasar.

Sebagaimana penelitian kualitatif yang menjadi instrumen atau alat penelitian adalah peneliti itu sendiri atau Human instrument. Akan tetapi, peneliti tetap membutuhkan alat bantu pendukung yang berhubungan dengan teknik pengumpulan data.

Dengan indikator lembar observasi sebagai berikut;

Tabel 1 Indikator lembar observasi

\begin{tabular}{|c|c|c|c|}
\hline No. & Komponen & Indikator & Keterangan \\
\hline \multirow[t]{2}{*}{1.} & \multirow[t]{2}{*}{ Isi portofolio } & $\begin{array}{l}\text { Guru memberikan tugas sesuai dengan } \\
\text { kompetensi dasar yang ada }\end{array}$ & \\
\hline & & $\begin{array}{l}\text { Guru memberikan kesempatan kepada } \\
\text { siswa untuk melakukan perbaikan tugas }\end{array}$ & \\
\hline \multirow[t]{3}{*}{2.} & \multirow{3}{*}{$\begin{array}{l}\text { Kriteria penilaian isi } \\
\text { portofolio }\end{array}$} & Guru menyusun format penilaian & \\
\hline & & $\begin{array}{l}\text { Guru melibatkan siswa dalam proses } \\
\text { penilaian }\end{array}$ & \\
\hline & & $\begin{array}{l}\text { Guru memberikan catatan pada portofolio } \\
\text { siswa }\end{array}$ & \\
\hline 3. & $\begin{array}{l}\text { Bentuk penyajian } \\
\text { portofolio }\end{array}$ & $\begin{array}{l}\text { Kelengkapan portofolio yang disusun, } \\
\text { yaitu: sampul, identitas peserta didik, } \\
\text { daftar isi dokumen, batasan dokumen, } \\
\text { catatan guru dan orang tua. }\end{array}$ & \\
\hline
\end{tabular}

Selanjutnya, pedoman wawancara perlu disusun agar proses wawancara tidak menyimpang dari fokus penelitian. Wawancara ini bertujuan untuk memperoleh data melalui tanya jawab secara langsung. Dengan kisi-kisi sebagai berikut; 
Tabel 2 Indikator pedoman wawancara

\begin{tabular}{|l|l|}
\hline Aspek & \multicolumn{1}{|c|}{ Indikator } \\
\hline \multirow{4}{*}{ Guru } & Isi portofolio \\
\cline { 2 - 3 } & Kriteria penilaian isi portofolio \\
\cline { 2 - 3 } & $\begin{array}{l}\text { Menentukan format dan skala penilaian dalam menilai } \\
\text { portofolio peserta didik }\end{array}$ \\
\cline { 2 - 3 } & Catatan atau keterangan deskriptifyang diberikan \\
\cline { 2 - 3 } & Bentuk penyajian penilaian portofolio \\
\cline { 2 - 2 } & Kendala guru dalam melaksanakan penilaian portofolio \\
\hline
\end{tabular}

Dalam kegiatan menganalisis data yang diperoleh peneliti, peneliti menggunakan model Miles and Hubermen (1990) dalam mukhtar (2013:135) tersebut untuk menganalisis data yang telah ada. Adapun model tersebut adalah dengan melakukan tahap-tahap yang diawali dengan mengumpulkan data, mereduksi, mendisplay data, dan memverifikasi atau menarik kesimpulan akhir. Kegiatan ini dikembangkan oleh peneliti dengan mengacu kepada pendapat Mukhtar (2013:135) dengan model Miles dan Huberman (1990) tersebut.

Dengan demikian yang dilakukan peneliti dalam kegiatan menganalisis ini adalah melakukan tahap-tahap menganalisis data sebagai berikut:

1. Mengumpulkan data, yaitu semua hasil dari data kegiatan observasi dan wawancara yang dilakukan, yang disebut data mentah;

2. Mereduksi data, setelah terkumpul peneliti menyeleksi data, menyederhanakan, memfokuskan, dan mengelompokkan data yang telah diperoleh di lapangan. Setelah itu peneliti melakukan abstraksi atau membuat ringkasan data;

3. Mendisplay data, merangkai informasi dan mengecek keabsahan dari data dalam upaya mengambil kesimpulan;

4. Memverifikasi data, membuat kesimpulan, menganalisis, dan memutuskan bagaimana pelaksanaan penilaian portofolio;

5. Membuat laporan;

Setelah melakukan langkah-langkah tersebut, kemudian peneliti akan mendapatkan hasil penelitian, dengan mengembangkan data yang diperoleh dari instrument pemerolehan data yang telah dibuat oleh peneliti sebelumnya. Dengan demikian peneliti akan mendapatkan jawaban dari rumusan masalah pada penelitian penelitian yang dilakukan oleh peneliti. Dalam penelitian deskriptif kualitatif ini hanya didapatkan hasil berupa fakta-fakta yang 


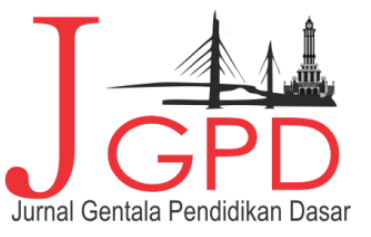

JURNAL GeNTALA PENDIIIKAN DASAR Vol. 4 No. 2 December 2019, Page I90-200 P-ISSN : 2614-7092, E-ISSN : 2621-966II

Available Dnline at Web : http://online-journal.unja.ac.id/index.php/gentala email : penyunting.jurnal.q-pgsd国unja.ac.id

diperoleh di lapangan tanpa merekayasa hasil temuan tersebut agar diperoleh data yang asli berdasarkan kenyataan yang terjadi di lapangan.

Adapun prosedur atau tahap-tahap yang dilakukan oleh peneliti dalam pelaksanaan penelitian adalah sebagai berikut.

1. Tahap Persiapan

a. Menyusun Instrumen Penelitian

Penyusunan instrument penelitian ini disusun berdasarkan tujuan penelitian dan jenis data yang di jadikan sumber penelitian, instrument yang digunakan dalam mengumpulkan data adalah observasi, wawancara dan dokumentasi.

b. Mendatangi Informan

Agar dalam pelaksanaan penelitian tidak terjadi kesalahpahaman bagi responden, maka penelitian perlu mendatangi responden untuk memberi informasi seperlunya kepada responden.

2. Tahap Pelaksanaan Penelitian

Kegiatan yang dilakukan pada tahap ini adalah mengumpulkan data dengan instrumen-instrumen yang sudah di persiapkan, mengelola data, menganalisis data, dan menyimpulkan data. Dalam kegiatan ini peneliti membawa surat izin dari Fakultas Keguruan dan Ilmu Pendidikan Universitas Jambi untuk mengambil data di lapangan.

3. Tahap Penyelesaian

Kegiatan yang dilakukan dalam tahap ini adalah menyusun data-data yang telah di peroleh dan analisis dalam bentuk laporan hasil penelitian yang di tempatkan pada BAB IV dan BAB V.

\section{HASIL PENELITIAN DAN PEMBAHASAN}

\section{Hasil penelitian}

Berdasarkan wawancara yang dilakukan, didapat data bahwa sebelum guru memutuskan isi apa yang akan dibuat peserta didik untuk mengisi portofolionya guru membuat persiapan dalam menilai diantaranya; 1) menyesuaikan tugas dengan kurikulum yang dijalankan saat ini yaitu K13,2) menentukan butir-butir apa saja yang harus didapat dalam tugas portofolio, 3) menentukan panjang portofolio yang dibuat, dan 4) mempunyai pedoman penskoran. 


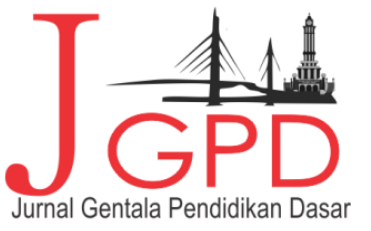

JURNAL GeNTALA PENDIDIKAN DASAR Vol. 4 No. 2 December 2019, Page I90-200

P-ISSN : 2614-7092, E-ISSN : 2621-961I

Available Dnline at Web : http://online-journal.unja.ac.id/index.php/gentala email : penyunting.jurnal.q-pgsd国unja.ac.id

Selanjutnya hasil isi portofolio peserta didik antara lain dapat berupa; ulangan harian, laporan membaca buku, lembar penilaian diri, lembar penilaian antar tema, dan untuk di kelas 1 juga dimasukkan buku pr, buku latihan, tugas dikte serta mewarnai. Isi portofolio tersebut juga bersumber dari buku LKS peserta didik yang disediakan oleh pihak sekolah, yang dikembangkan dengan kurikulum 2013, sehingga kompetensi yang ada dalam tugas tersebut terdalam dalam kurikulum 2013.

\section{Kriteria dan Format Penilaian Isi Portofolio}

Dalam merencanakan penilaian portofolio, guru menyusun pengembangan sistem penilaian dan perangkat pembelajaran, menentukan jenis tagihan serta bentuk instrument yang akan digunakan. Pengembangan sistem penilaian dijadikan satu dengan silabus. Perangkat pembelajaran yang dibuat meliputi: Program Tahunan, Program Semester, dan Rencana Pembelajaran. Rincian pengembangan sistem penilaian yang dijadikan satu dengan silabus, yaitu berisi satuan pendidikan, tema/subtema, kelas, kompetensi isi, kompetensi dasar, indikator, tujuan pembelajaran, materi pokok, alokasi waktu, sumber pembelajaran, dan penilaian. Penilaian, meliputi jenis tagihan, kriteria penilaian, dan lembar penilaian. Dalam membuat silabus dan sistem penilaian ini berpedoman pada kurikulum yang berlaku pada saat ini, yaitu kurikulum 2013.

Namun, walaupun tidak mengembangkan kriteria penilaian guru dapat memberikan skor untuk tugas yang telah dikerjakan peserta didik. Hal tersebut tergambar pada gambar di bawah ini.

Dari hasil wawancara didapat data bahwa guru menilai tugas peserta didik berdasarkan konsep yang guru miliki terhadap materi tersebut. Setelah melakukan penilaian terhadap tugas peserta didik yang menghasilkan skor rentang 10-100. Guru menuliskan skor peserta didik tersebut pada buku penilaian harian, serta agenda harian guru. Data yang didapat dari hasil wawancara dengan guru kelas IVC adalah bahwa guru kelas tidak mengembangkan format penilaian dalam RPP ataupun dalam lembar tugas peserta didik, Hal tersebut terjadi karena dari segi waktu yang tidak mencukupi untuk membuat format penilaian. Sehingga catatan yang seharusnya guru tuliskan di format penilaian untuk mengomentari hasil tugas peserta didik, langsung guru tulis pada lembar tugas tersebut, berupa kata motivasi seperti "Tingkatkan Lagi”. Sebagai instrumen penilaian, portofotio yang guru ambil difokuskan pada dokumen tentang kerja siswa yaitu 'bukti' tentang apa yang dapat dilakukan oleh peserta didik, bukan apa yang tidak dapat dikerjakan. 


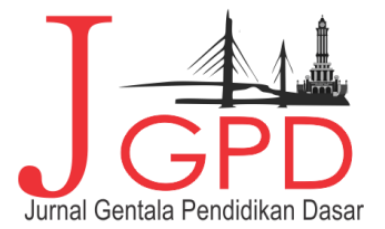

JURNAL GeNTALA PENDIDIKAN DASAR Vol. 4 No. 2 December 2019, Page I90-200

P-ISSN : 2614-7092, E-ISSN : 2621-961I

Available Dnline at Web : http://online-journal.unja.ac.id/index.php/gentala

email : penyunting.jurnal.g-pgsd国unja.ac.id

\section{Bentuk Penyajian Penilaian Portofolio}

Berdasarkan hasil Wawancara dengan dapat diketahui bahwa indikator-indikator dalam penilaian portofolio adalah sebagai berikut,

a. Nilai hasil tes formatif dan sumatif. Tes formatif diselenggarakan setelah selesai satu kompetensi dasar, sedangkan tes sumatif diselenggarakan pada akhir semester. Nilai hasil tes tersebut dicatat dalam buku daftar nilai guru serta dicatat pula dalam rekapitulasi nilai perorangan masing-masing peserta didik dengan mencantumkan kompetensi dasar/materi, kapan tes dilaksanakan, berapa nilai yang diperoleh peserta didik, rata-rata nilai dari tes formatif dan sumatif untuk didokumentasikan dalam portofolio masing-masing peserta didik.

b. Tugas-tugas terstruktur (Pekerjaan Rumah). Tugas-tugas tersruktur adalah tugas yang dikerjakan oleh peserta didik untuk mendalami atau memperluas penguasaan materi pelajaran. Tugas yang diberikan dapat berupa soal-soal latihan yang terdapat dalam Lembar Kegiatan Peserta didik (LKS),. Berkas tugas setelah diberi nilai, dikembalikan pada peserta didik untuk dilampirkan pada portofolio masing-masing peserta didik.

Saat melakukan penyusunan portofolio, guru tidak tergambar meminta peserta didik untuk melakukan self assessment. Bagian Portofolio yang dikembangkan oleh guru hanya terdapat halaman depan dan identitas peserta didik. Peneliti tidak melihat adanya, daftar isi dokumen, batasan dokumen, catatan guru dan orang tua.

Penggunaan portofolio untuk penilaian memerlukan banyak waktu dari guru untuk melakukan penskoran; apalagi kalau kelasnya besar. Penggunaan portofolio tergantung pada kemampuan peserta didik dalam menyampaikan uraian secara tertulis. Selama peserta didik belum lancar berbahasa tulis Indonesia, penggunaan portofolio akan merupakan beban tambahan yang memberatkan sebagian besar peserta didik. Tetapi, jika penilaian portofolio digunakan dengan baik dan benar, maka dapat memperkuat hubungan antara proses pembelajaran dengan penilaian.

\section{Pembahasan}

Untuk menyimpan/mendokumentasikan hasil penilaian formatif, sumatif, tugas-tugas terstruktur dan berkas hasil karya peserta didik, yang ditulisi identitas masing-masing peserta didik, terdiri dari judul (portofolio), mata pelajaran, semester, nama peserta didik, kelas, tahun ajaran kemudian rekap nilai ini ditulis didalam buku nilai. Nilai hasil tes formatif dan 


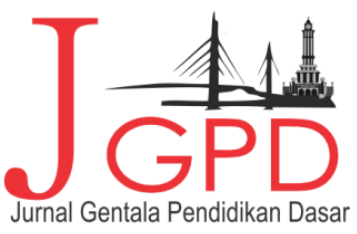

JURNAL GeNTALA PENDIDIKAN DASAR Vol. 4 No. 2 December 2019, Page I90-200 P-ISSN : 2614-7092, E-ISSN : 2621-961I

Available Dnline at Web : http://online-journal.unja.ac.id/index.php/gentala email : penyunting.jurnal.q-pgsd国unja.ac.id

sumatif dicatat dalam rekapitulasi nilai perorangan dari masing-masing peserta didik dengan mencantumkan mata pelajaran, nama peserta didik, kelas/nomor, semester, tahun ajaran, materi yang dinilai (kompetensi dasar), tanggal pelaksanaan, nilai yang diperoleh, keterangan, rata-rata dari nilai tes formatif dan sumatif. Sedangkan nilai tugas tersruktur dicatat dalam rekapitulasi nilai tugas terstruktur dengan mencantumkan nama peserta didik, kelas/nomor, mata pelajaran, tahun ajaran, jenis tugas, aspek penilaian, nilai, paraf, dan keterangan. Jenis tugas yang diberikan meliputi mengerjakan soal-soal yang ada dalam buku paket peserta didik, maupun yang diberikan guru. Aspek penilaian meliputi unsur : pemahaman, keterampilan, dan sikap. Tetapi, data yang didapat oleh peneliti bagian portofolio map belum lengkap, hanya terdiri sampul dan identitas peserta didik.

Lebih lanjut, Pramono (2004,171-173) menjelaskan perencanaan portofolio ada 8 tahapan yaitu.

1. Menentukan tujuan dan fokus portofolio

2. Menentukan isi portofolio

3. Mengembangkan kriteria penilaian

4. Menyusun format penilaian

5. Mengidentifikasi pengorganisasian portofolio

6. Menggunakan portofolio dalam praktik

7. Menilai pelaksanaan portofolio

8. Menilai portofolio secara umum

Setelah perencanaan itu selesai, guru tinggal memberikan catatan atau komentar dan keputusan terhadap dokumen yang telah dibuat oleh peserta didik.

Guru telah mengembangkan teknik penilaian sesuai dengan kompetensi yang ditentukan. Hal tersebut tergambar dari, pemilihan tes tertulis dipilih oleh guru dikarenakan tugas yang diberikan berupa kompetensi menulis, sehingga ada kesesuaian antara teknik penilaian dengan kompetensi yang ditentukan agar tujuan penilaian portofolio tercapai. Hal tersebut sesuai dengan pendapat Masnur Muslich (2011: 33) yang mengemukakan bahwa guru hendaknya memiliki pengetahuan dan kemahiran tentang berbagai metode dan teknik penilaian sehingga dapat memilih dan melaksanakan dengan tepat metode dan teknik penilaian yang dianggap paling sesuai dengan tujuan dan proses pembelajaran, serta pengalaman yang telah ditetapkan. 


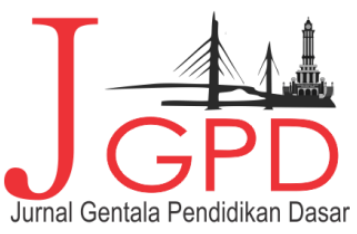

JURNAL GeNTALA PENDIDIKAN DASAR Vol. 4 No. 2 December 2019, Page I90-200 P-ISSN : 2614-7092, E-ISSN : 2621-961I

Available Dnline at Web : http://online-journal.unja.ac.id/index.php/gentala email : penyunting.jurnal.q-pgsd国unja.ac.id

Pelaksanaan penilaian portofolio dalam pembelajaran oleh guru kelas pada bentuk penyajian portofolio. Bentuk penyajian portofolio yang dikembangkan guru adalah berupa map dan buku. Bagian portofolio tersebut terdiri dari cover dan identitas peserta didik. Guru terlebih dahulu menyelesaikan penilaian beberapa tugas peserta didik, sehingga penyusunan portofolio masih belum terjadwal dengan baik. Guru meminta sisiwa untuk memasukkan hasil tugas-tugas yang telah dinilai ke dalam map portofolio masing-masing. Dari kegiatan tersebut tergambar bahwa guru telah melibatkan peserta didik secara langsung dalam kegiatan penyusunan portofolio.

Dalam melaksanakan penilaian portofolio hambatan yang dihadapi oleh guru adalah pengelolaan waktu, terkadang waktu yang telah rencanakan belum maksimal dimanfaatkan, selain itu pemahaman peserta didik terhadap tugas yang diberikan terkadang ada yang tidak mampu mencapai kompetensi yang telah ditentukan. Hal ini sejalan dengan yang diterbitkan oleh Depdiknas,2004. Yang memaparkan kekurangan dari penggunaan portofolio antara lain; penggunaan portofolio yang tergantung pada kemampuan peserta didik dalam menyampaikan uraian secara tertulis. Selama peserta didik belum lancar berbahasa tulis Indonesia, penggunaan portofolio akan merupakan beban tambahan yang memberatkan sebagian besar peserta didik.

Penggunaan portofolio untuk penilaian memerlukan banyak waktu dari guru untuk melakukan penskoran; apalagi kalau kelasnya besar. Tetapi, jika penilaian portofolio digunakan dengan baik dan benar, maka dapat memperkuat hubungan antara proses pembelajaran dengan penilaian. Oleh karena itu, portofolio yang ditugaskan untuk dibuat perlu disesuaikan dengan kemampuan peserta didik berbahasa tulis Indonesia dan waktu yang tersedia bagi guru untuk membacanya.

\section{KESIMPULAN DAN IMPLIKASI}

\section{Kesimpulan}

Isi portofolio peserta didik yang dikembangkan oleh guru antara lain, ulangan harian, laporan membaca buku, lembar penilaian diri, lembar penilaian antar tema, dan untuk di kelas 1 juga dimasukkan buku pr, buku latihan, tugas dikte serta mewarnai. Isi portofolio tersebut juga bersumber dari buku LKS peserta didik yang disediakan oleh pihak sekolah, 


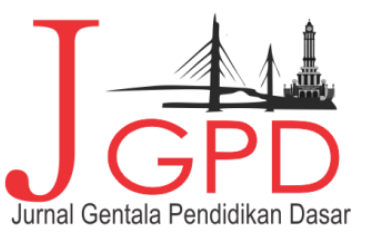

JURNAL GeNTALA PENDIIIKAN DASAR Vol. 4 No. 2 December 2019, Page I90-200 P-ISSN : 2614-7092, E-ISSN : 2621-966II

Available Cnline at Web : http://anline-journal.unja.ac.id/index.php/gentala email : penyunting.jurnal.q-pgsd国unja.ac.id

yang dikembangkan dengan kurikulum 2013, sehingga kompetensi yang ada dalam tugas tersebut terdalam dalam kurikulum 2013.

Guru hendaknya siap untuk membuat krteria penilaian secara tertulis dan baku ketika telah memutuskan untuk menggunakan penilaian portofolio agar penilaian yang dilakukan sesuai dengan indikator pencapaian yang ada. Namun, dari data yang terlihat guru sering kali melakukan penilaian tugas peserta didik diluar jam pembelajaran sehingga keterlibatan peserta didik dalam proses penilaian masih belum tergambar. Hendaknya guru perlu melibatkan peserta didik dalam proses penilaian agar peserta didik mengetahui kekurangan dan kelebihan dalam dirinya.

Bentuk penyajian portofolio yang dikembangkan guru adalah berupa map dan buku. Bagian portofolio tersebut terdiri dari cover dan identitas peserta didik. Guru terlebih dahulu menyelesaikan penilaian beberapa tugas peserta didik, sehingga penyusunan portofolio masih belum terjadwal dengan baik. Bagian portofolio map belum lengkap, hanya terdiri sampul dan identitas peserta didik.

\section{Implikasi}

Penelitian ini dapat berguna menambah informasi dalam bidang pelaksanaan penilaian portofolio di Sekolah Dasar dan dapat memperkaya wawasan ilmu pengetahuan mengenai pelaksanaan penilaian di sekolah.

\section{Saran}

Saran yang dapat penulis berikan terkait dengan pelaksanaan penilaian portofolio yang dilakukan oleh guru di SDN 80/I Muara Bulian adalah:

1. Sekolah hendaknya lebih mengoptimalkan fasilitas-fasilitas yang ada untuk menunjang agar pelaksanaan penilaian portofolio dapat dioptimalkan dengan baik.

2. Diharapkan guru untuk menyusun dan merencanakan kriteria, format penilaian dan bentuk penyajian portofolio sesuai dengan indikator pencapaian yang ditentukan sebelum melaksanakan penilaian portofolio

\section{DAFTAR PUSTAKA}

Adisusila. (2014). Pembelajaran Nilai Karakter VCT Sebagai Inovasi Pendekatan Pembelajaran Afektif. Jakarta: Rajawali

Arifin. (2010). Dalam makalah Penilaian Portofolio Universitas Pendidikan Indonesia. (Online). http://www.penilaian-portofolio-makalah/. Diakses pada tanggal 29 Agustus 2017 


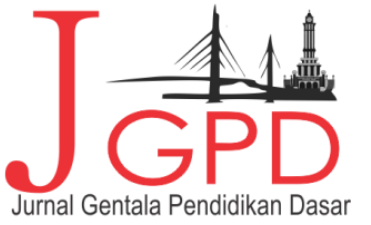

JURNAL geNTALA PENDIDIKAN DASAR Vol. 4 No. 2 December 2019, Page 190-200 P-ISSN : 2614-7092, E-ISSN : 2621-961I

Available Dnline at Web : http://online-juurnal.unja.ac.id/index.php/gentala email : penyunting.jurnal.g-pgsd国unja.ac.id

Chan, F., Kurniawan, A. R., Herawati, N., Efendi, R. N., \& Mulyani, J. S. (2019). Strategi Guru Dalam Mengelola Kelas di Sekolah Dasar. International Journal of Elementary Education, 3(4), 439-446.

Depdiknas. (2004) . Pedoman Pengembanagan Portofolio untuk Penilaian. (Online). http://www.pedoman-pengembangan-portofolio/. Diakses pada tanggal 29 Agustus 2017

Direktorat Pembinaan Sekolah dasar Kementrian Pendidikan dan Kebudayaan 2016. (Online) http://www.Panduan-Pendidikan-untuk-sekolah-dasar/ Diakses pada tanggal 29 Oktober 2017

E-jurnal FKIP PGSD Universitas Sanata Dharma. Soewardi. (2008). (Online). http://www.01Penilaianportofolio(Slamet Soewardi)/. Diakses pada tanggal 29 Agustus 2017

Kusaeri. (2014). Penilaian dan Teknik Penilaian Proses dan Hasil Belajar dalam Kurikulum 2013. Yogyakarta: Ar. Ruzz Media

Kuntarto, E., Alirmansyah, A., \& Kurniawan, A. R. (2019). Kemampuan Mahasiswa PGSD dalam Merancang dan Melaksanakan Pembelajaran Berbasis High Order Of Thinking Skills. Jurnal Kiprah, 7(2), 107-116.

Kurniawan, A. R., Chan, F., Abdurrohim, M., Wanimbo, O., Putri, N. H., Intan, F. M., \& Samosir, W. L. S. (2019). Problematika Guru Dalam Melaksanakan Program Literasi Di Kelas IV Sekolah Dasar. EduStream: Jurnal Pendidikan Dasar, 3(2), 31-37.

Masnur, Muslich. (2010). Penilaian Berbasis Kelas dan Kompetensi. Yogyakarta: Diva Press Mukhtar, (2013). Metode Praktis Penelitian Deskriptif Kualitatif. Jakarta: Gaung

Patandean. (2013). Penilaian Portofolio dalam Pembelajaran Fisika Berbasis Inquiry Terbimbing. Universitas Negeri Makassar. (Online) http://www.Penilaian-portofoliodalam-pembelajaran. Diakses tanggal 29 oktober 2017

Pramono. (2014). Panduan Penilaian Kegiatan Belajar Mengajar. Jogjakarta: Diva Press

Resmini, Novi. (2010). Penilaian dalam Pembelajaran Bahasa Indonesia. Universitas Pendidikan Indonesia. (Online) http://www.Penilaian_dalam_pengajaran_bahasa. Diakses tanggal 29 oktober 2017

Salinan Permendikbud No.23 Tahun 2016 Tentang Standar Penilaian Pendidikan. (Online). http://www.Permendikbud-tahun2016-nomor023/. Diakses pada tanggal 29 Agustus 2017

Sukardi. (2015). Penilaian Program Pendidikan dan Kepelatihan. Jakarta: Bumi Aksara

Wahyuni, Meila Tri. 2009. Peranan Penilaian Portofolio dalam Mengoptimalkan Kemampuan Berpikir Siswa pada Pembelajaran PKn di SDN BI Tlogowaru Malang. (Online). http://www.peranan-penilaian-portofolio- /. Diakses pada tanggal 29 Agustus 2017.

Widyawati. (2006). Pelaksanaan Penilaian Portofolio Pada Mata Pelajaran Pendidikan Kewarganegaraan Kelas X SMAN 2 Semarang Tahun 2005-2006. (Online). http://www.penilaian-portofolio- /. Diakses pada tanggal 29 Agustus 2017.

Yamin, Martinus. (2012). Strategi Pembelajaran Berbasis Kompetensi. Jakarta: Referensi. 